This item was submitted to Loughborough's Research Repository by the author.

Items in Figshare are protected by copyright, with all rights reserved, unless otherwise indicated.

\title{
Electrodeposition of zinc-manganese alloy coatings from ionic liquid electrolytes
}

PLEASE CITE THE PUBLISHED VERSION

PUBLISHER

(C) Maney Publishing

VERSION

AM (Accepted Manuscript)

LICENCE

CC BY-NC-ND 4.0

\section{REPOSITORY RECORD}

Chung, P.P., P.A. Cantwell, G.D. Wilcox, and Gary W. Critchlow. 2009. "Electrodeposition of Zinc-manganese Alloy Coatings from lonic Liquid Electrolytes". figshare. https://hdl.handle.net/2134/4411. 
This item was submitted to Loughborough's Institutional Repository (https://dspace.lboro.ac.uk/) by the author and is made available under the following Creative Commons Licence conditions.

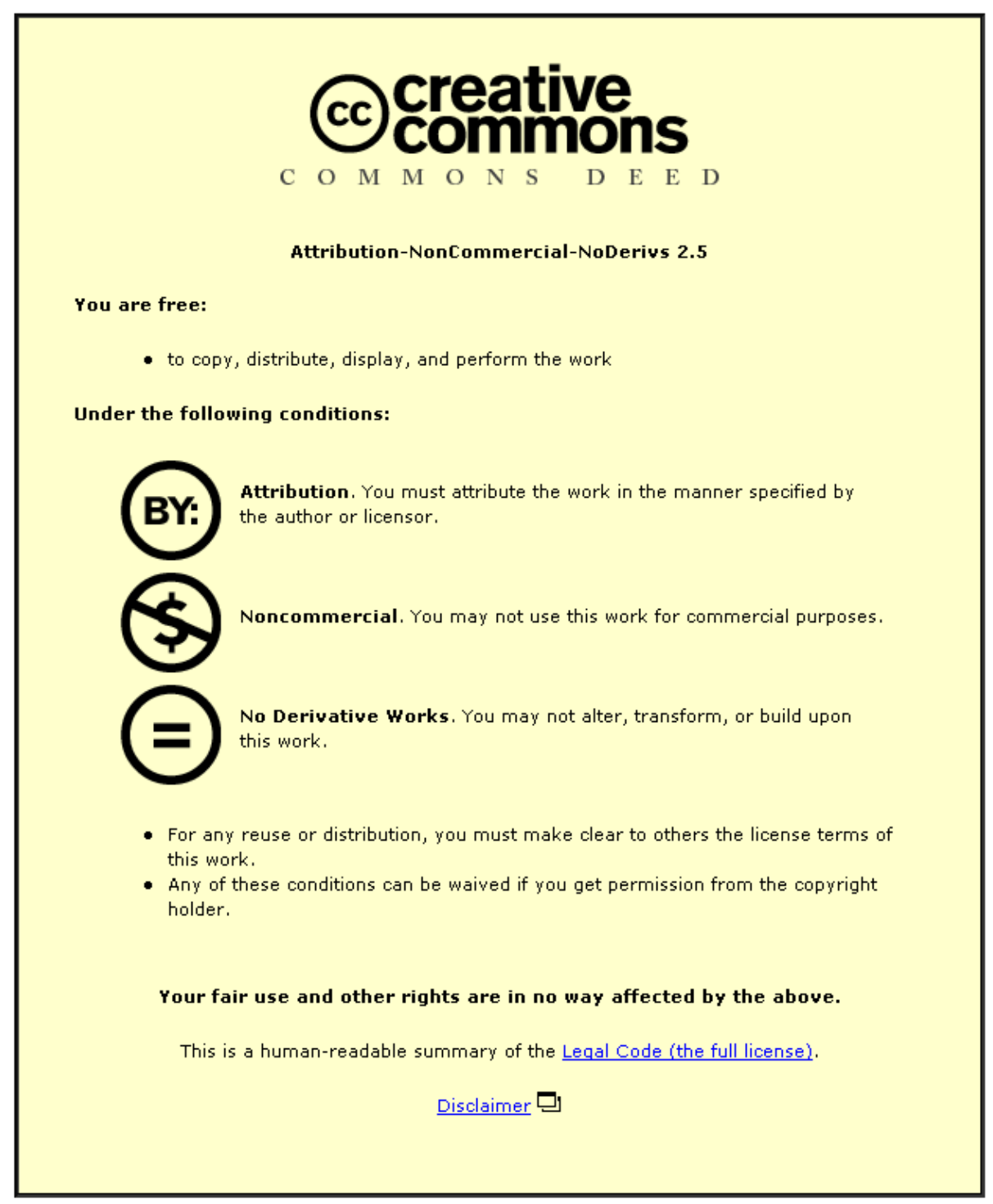

For the full text of this licence, please go to: http://creativecommons.org/licenses/by-nc-nd/2.5/ 


\title{
The Electrodeposition of Zinc-Manganese Alloy Coatings from Ionic Liquid Electroltyes
}

\author{
P.P.Chung, P.A.Cantwell, G.D.Wilcox and G.W.Critchlow \\ Institute of Polymer Technology and Materials Engineering, \\ Loughborough University, \\ Loughborough, \\ Leicestershire. LE11 3TU. \\ U.K.
}

\begin{abstract}
Electrodeposited zinc-manganese alloys have been found to have potentially attractive corrosion resisting characteristics for ferrous substrates. However, researchers have found their formation problematic from aqueous electrolytes, due particularly to the reactive nature of manganese and its low reduction potentials. The present investigations examine the possibility of electrodepositing this alloy utilising an ionic liquid electrolyte. In this manner electrolytes based upon manganese and zinc chlorides and boric acid were made by dissolution in a 2:1 molar ratio urea: choline chloride solvent. Physical measurements of electrolyte characteristics as well as pertinent electrochemical information on alloy electrodeposition were obtained to examine the efficacy of this metal/electrolyte combination.
\end{abstract}

\section{Introduction}

Zinc-based coatings are commonly applied to the surface of carbon steels to sacrificially protect them from corrosion in a range of environments. Zinc has been generally deposited from four main electrolytes namely cyanide-based, acid sulphate, chloride and alkaline zincate [1-3]. Although zinc coatings are well known as effective sacrificial treatments, this protection is not acceptable under severe atmospheric conditions or for long term applications unless the coatings are particularly thick. Zinc alloy electrodeposits are now widely applied where extra corrosion protection is required [4]. Of these alloys ZnMn has proved to be highly effective but has remained difficult to utilise commercially because of its low cathode current efficiencies and unstable electrolytes, particularly when higher manganese alloy contents are required [5-9]. One of the key factors influencing the $\mathrm{Zn}-\mathrm{Mn}$ electrodeposition reaction 
is the high activity displayed by manganese. In aqueous environments manganese has a standard electrode potential of $-1.18 \mathrm{~V}$ vs SHE. Therefore in conventional electrolytes the electrochemical reduction of manganese will be associated with potentials where concurrent hydrogen evolution is problematic. This is more evident as the required manganese content in the alloy increases. One avenue of approach is to electrodeposit the alloy from a non-aqueous environment. Molten salt electrolytes and organic solvents are problematic due to their high temperatures and low vapour pressures respectively. Another, relatively unusual approach is to electrodeposit the zinc alloy from an electrolyte based upon ionic liquids.

Ionic liquids are solvents that are solely composed of ions and have melting points below $100^{\circ} \mathrm{C}$. They are, therefore, known as room temperature molten salts. Being non-aqueous based, their propensity for promoting hydrogen evolution is much reduced and subsequently the cathode current efficiency is significantly increased. As a result, ionic liquids could be used to electrodeposit some of the more active metals such as aluminium and manganese. Ionic liquids have significantly wider electrochemical windows as a result of their higher electrochemical stability over a larger potential range [10]. In addition, many of them have negligible vapour pressures and therefore are not flammable or explosive [11]. Moreover, with the relatively low vapour pressure, ionic liquids do not evaporate and hence do not contribute to air pollution, giving an environmental friendly characteristic.

Electrodeposition of zinc and its alloys from ionic liquid electrolytes has recently been investigated. Mixtures of substituted quaternary ammonium salts such as choline chloride with urea have been reported [12] and electrodeposition of $\mathrm{Zn}$ and $\mathrm{Zn}$-Sn from these types of solvents have also been studied recently [13]. Although the electrodeposition of $\mathrm{Zn}-\mathrm{Mn}$ has been achieved recently from ionic liquids [14] its formation from choline chlorideurea-based formulations has not been reported to the knowledge of the authors.

The aim of these reported investigations was to examine the electrodeposition of $\mathrm{Zn}-\mathrm{Mn}$ alloys from compositions of zinc chloride and manganese chloride in 
2:1 urea/choline chloride ionic liquids by performing physical and electrochemical characterisations of the electrolyte formulations, i.e. viscosity, conductivity and cathodic polarisation measurements. After identifying the optimum composition of ionic liquid electrolyte, the second objective was to electrodeposit Zn-Mn from the compositions of interest. Morphological and compositional analyses were then carried out essentially to study the morphology and the manganese content obtained. Suitable addition agents were identified and added to the ionic liquid in order to assess their ability to improve the electrodeposition process.

\section{Experimental Techniques}

\section{Preparation of Electrolytes}

Ionic liquid formulations were acheived by combining urea with choline chloride $(\mathrm{ChCl})$ in a $2: 1$ molar ratio and heating to a temperature of $80^{\circ} \mathrm{C}$, with continuous magnetic stirring, until a clear colourless liquid formed. Different concentration levels of zinc (II) chloride $\left(\mathrm{ZnCl}_{2}\right)$, hydrated manganese (II) chloride $\left(\mathrm{MnCl}_{2} \cdot 4 \mathrm{H}_{2} \mathrm{O}\right)$ or monohydrated manganese (II) chloride $\left(\mathrm{MnCl}_{2} \cdot \mathrm{H}_{2} \mathrm{O}\right)$ and other addition agents, were then added into the mixture. The stirring was then continued for approximately 30 minutes in order to reach a homogenous state.

\section{Viscosity}

Viscosities of 2:1 urea/ChCl ionic liquid electrolytes containing different levels of $\mathrm{ZnCl}_{2}$ and $\mathrm{MnCl}_{2} .4 \mathrm{H}_{2} \mathrm{O}$ were measured using a Haake VT500 viscometer. The measurements were performed at $25^{\circ} \mathrm{C}, 40^{\circ} \mathrm{C}, 60^{\circ} \mathrm{C}$ and $80^{\circ} \mathrm{C}$.

\section{Conductivity}

A conductivity measuring bridge, type $\mathrm{MC} 3$, was used to perform conductivity 
measurements of ionic liquids containing different concentration levels of $\mathrm{ZnCl}_{2}$ and $\mathrm{MnCl}_{2} \cdot 4 \mathrm{H}_{2} \mathrm{O}$. The conductivity tests were carried out at $25^{\circ} \mathrm{C}, 40^{\circ} \mathrm{C}$, $60^{\circ} \mathrm{C}$ and $80^{\circ} \mathrm{C}$.

\section{Removal of Water Crystallisation from Manganese Chloride}

Hydrated manganese (II) chloride $\left(\mathrm{MnCl}_{2} \cdot 4 \mathrm{H}_{2} \mathrm{O}\right)$ was transformed to its mono hydrated state by heating at $200^{\circ} \mathrm{C}$ under vacuum for 12 hours in a laboratory vacuum furnace and subsequently measuring the weight loss. X-ray diffraction was undertaken to confirm this final state of hydration.

\section{Electrochemical Investigations}

An EG\&G potentiostat / galvanostat model 263A controlled with PowerSuite software was employed to perform cathodic polarisation measurements and potentiostatic electrodepositions. The electrochemical experiments were conducted in a three-electrode electrochemical cell. For cathodic polarisation measurements the working electrode (cathode) was either a copper coil wire or a copper foil (both $99.99 \%$ ) with an active area of $1 \mathrm{~cm}^{2}$. For potentiostatic electrodeposition, the working electrode was copper foil. The counter electrode was platinum immersed directly in the 2:1 urea/ChCl ionic liquid. The working electrode and counter electrode were separated by a membrane allowing the flow of current between both electrodes but reducing the likelihood of cross contamination of oxidation and reduction products between the two cell compartments. The reference electrode was a silver wire (99.98\%) and all potentials quoted are measured against it.

For cathodic polarisation curves potential sweeps were performed over a range of $-0.2 \mathrm{~V}$ to $-2.0 \mathrm{~V}$ at a scan rate of $200 \mathrm{mV} / \mathrm{s}$. The potentiostatic electrodeposition investigations were conducted at potentials in the range 
from $-1.0 \mathrm{~V}$ to $-1.8 \mathrm{~V}$ for 10 minutes. For potentiostatic electrodeposition performed at $40^{\circ} \mathrm{C}$ and $60^{\circ} \mathrm{C}$, a glycerol bath was used to maintain the temperature of the bulk electrolyte.

\section{Copper Electrode Preparation}

The copper coil wire was masked using Lacomit Varnish, leaving only the tip for electrochemical reaction. The copper coupon was cut to the appropriate size and then cleaned with detergent, rinsed with deionised water, and dried off. An active area of $1 \mathrm{~cm}^{2}$ was prepared by masking off the remaining area using chemically resistant tape. Both types of cathodes were then immersed into 50 vol.\% (SG 1.42) nitric acid for 1 minute to remove oxides from the surface. They were then rinsed with deionised water, followed by acetone and finally dried. The samples was placed immediately into the electrolytes in order to prevent the reformation of oxide on the surface.

\section{Scanning Electron Microscopy (SEM)}

A Cambridge Stereoscan 360 scanning electron microscope (SEM) equipped with energy dispersive X-ray spectroscopy (EDX) was used to examine the morphology and composition of the electrodeposits. The analysis was performed at the centre of each sample.

\section{Results and Discussion}

Figure 1 shows the viscosities of the 2:1 urea/ChCl with $\mathrm{ZnCl}_{2}$ and $\mathrm{MnCl}_{2} \cdot 4 \mathrm{H}_{2} \mathrm{O}$ as a function of temperature and composition. It is noticeable that the viscosities of the ionic liquid electrolytes examined ranged from approximately $100 \mathrm{mPa}$ s to about $500 \mathrm{mPa}$ s at room temperature, indicating that they were generally more viscous than common molecular solvents. Water has a dynamic viscosity of $0.891 \mathrm{mPa} s$ at 298K [15]. 
The data also show that 2:1 urea/ChCl containing $0.2 \mathrm{M} \mathrm{ZnCl}_{2}+0.9 \mathrm{M}$ $\mathrm{MnCl}_{2} .4 \mathrm{H}_{2} \mathrm{O}, 0.4 \mathrm{M} \mathrm{ZnCl}_{2}+0.7 \mathrm{M} \mathrm{MnCl}_{2} .4 \mathrm{H}_{2} \mathrm{O}, 0.5 \mathrm{M} \mathrm{ZnCl} 2+0.5 \mathrm{M} \mathrm{MnCl}_{2} .4 \mathrm{H}_{2} \mathrm{O}$ and $0.7 \mathrm{M} \mathrm{ZnCl}_{2}+0.4 \mathrm{M} \mathrm{MnCl}_{2} \cdot 4 \mathrm{H}_{2} \mathrm{O}$, respectively, had considerably lower viscosities than the benchmark solution, $2: 1 \mathrm{urea} / \mathrm{ChCl}$, at room temperature. Further investigations revealed that as the temperature increased to $40^{\circ} \mathrm{C}$, the viscosity of the $0.5 \mathrm{M} \mathrm{ZnCl}_{2}+0.5 \mathrm{M} \mathrm{MnCl}_{2} .4 \mathrm{H}_{2} \mathrm{O}$ electrolytes became relatively high compared to the bench mark electrolyte while the rest of the compositions remained less viscous. When the temperature increased to $60^{\circ} \mathrm{C}$, only $0.2 \mathrm{M} \mathrm{ZnCl} 2+0.9 \mathrm{M} \mathrm{MnCl}_{2} .4 \mathrm{H}_{2} \mathrm{O}$ and $0.4 \mathrm{M} \mathrm{ZnCl} 2+0.7 \mathrm{M}$ $\mathrm{MnCl}_{2} \cdot 4 \mathrm{H}_{2} \mathrm{O}$ had similar viscosities to the bench mark, whilst at $80^{\circ} \mathrm{C}$ both viscosities were slightly lower than the bench mark. In general, the viscosities of the ionic liquids decreased significantly as the temperatures increased. Viscosity of an electrolyte indicates the mobility of ions and subsequently influences the conductivity as well as the mass transport characteristics. As a result, the investigation of the viscosity of an ionic liquid is significant in identifying optimum conditions for an electrodeposition process.

Figure 2 illustrates the conductivity of $\mathrm{ZnCl}_{2}$ and $\mathrm{MnCl}_{2} \cdot 4 \mathrm{H}_{2} \mathrm{O}$ in $2: 1$ urea/ChCl as a function of temperature and composition. The graph indicates that the benchmark solution had the highest conductivity at $25^{\circ} \mathrm{C}, 40^{\circ} \mathrm{C}, 60^{\circ} \mathrm{C}$ and $80^{\circ} \mathrm{C}$. Conductivities of ionic liquids are usually lower than those of concentrated aqueous electrolytes and the conductivity of solution depends not only on the number of charge carriers but also on their mobility. As a result, the large constituent ions of the ionic liquids containing $\mathrm{ZnCl}_{2}$ and $\mathrm{MnCl}_{2} \cdot 4 \mathrm{H}_{2} \mathrm{O}$ may have reduced the ion mobility which, in turn, leads to lower conductivities. Among the mixtures, $2: 1$ urea/ $\mathrm{ChCl}$ containing $0.2 \mathrm{M} \mathrm{ZnCl}_{2}+$ $0.9 \mathrm{M} \mathrm{MnCl} 2.4 \mathrm{H}_{2} \mathrm{O}, 0.4 \mathrm{M} \mathrm{ZnCl} 2+0.7 \mathrm{M} \mathrm{MnCl} \mathrm{Zn}_{2} .4 \mathrm{H}_{2} \mathrm{O}$, and $0.5 \mathrm{M} \mathrm{ZnCl} 2+0.5 \mathrm{M}$ $\mathrm{MnCl}_{2} .4 \mathrm{H}_{2} \mathrm{O}$, respectively, had higher conductivities when compared with the other mixtures at the temperatures studied.

From the initial characterisations, which were concerned with the viscosity and conductivity of the ionic liquid electrolytes, $2: 1$ urea/ChCl containing $0.4 \mathrm{M}$ $\mathrm{ZnCl}_{2}+0.7 \mathrm{M} \mathrm{MnCl} \mathrm{M}_{2} .4 \mathrm{H}_{2} \mathrm{O}$ was identified to be the composition of interest at $40^{\circ} \mathrm{C}$ and $60^{\circ} \mathrm{C}$. As a result, further characterisations were carried out with addition of $0.4 \mathrm{M} \mathrm{NaCl}$ and $0.4 \mathrm{M} \mathrm{ChCl}$ respectively into $2: 1$ urea/ChCl with 
$0.4 \mathrm{M} \mathrm{ZnCl}_{2} / 0.7 \mathrm{M} \mathrm{MnCl}_{2} .4 \mathrm{H}_{2} \mathrm{O}$ in order to investigate the impact of $\mathrm{NaCl}$ and the additional $\mathrm{ChCl}$ on the ionic liquid.

In order to study the electrodeposition of zinc-manganese alloys, cathodic potential sweeps of ionic liquids containing $\mathrm{ZnCl}_{2}$ and $\mathrm{MnCl}_{2} .4 \mathrm{H}_{2} \mathrm{O}$ at different concentrations levels were carried out ito study the electrodeposition potential range for zinc and manganese respectively. Each curve was obtained as an average of four separate experiments, proving statistically consistent and reliable results. The curves were measured in one single potential sweep without reversal and with a potential ranging from $-0.2 \mathrm{~V}$ to $-2.2 \mathrm{~V}$. Figure 3 illustrates the data as a function of potential and composition. In general, as the potential became more negative, the current increased gradually until it reached a maximum peak (approximately $-0.7 \mathrm{~V}$ ). A drop in current occurred after the maximum peak, this could be due to mass transport limitations at the cathode surface. The current continued to decrease until a point where the curve was flat, indicating that the electrochemical process had reached a limiting current. The second part of the curve, which started to increase exponentially after the limiting current, indicated a secondary process commencing at ca. $-1.2 \mathrm{~V}$.

The concentration levels of zinc and manganese had an effect on the rate of mass transport as well. The electrolyte containing $0.4 \mathrm{M} \mathrm{ZnCl}_{2}+0.7 \mathrm{M}$ $\mathrm{MnCl}_{2} \cdot 4 \mathrm{H}_{2} \mathrm{O}$ had the highest limiting current and as a result, this was identified as the composition of interest to be studied further.

\section{Removal of Water of Crystallisation from Manganese Chloride}

The drying process noted earlier had been seen to remove three of the water of crystallisation associated with $\mathrm{MnCl}_{2} \cdot 4 \mathrm{H}_{2} \mathrm{O}$ reducing it to $\mathrm{MnCl}_{2} \cdot \mathrm{H}_{2} \mathrm{O}$. This was determined by x-ray diffraction, a sweep range of 10 to 60 degrees had been undertaken after the drying process had been completed. Figure 4 illustrates the diffraction pattern obtained.

As a result cathodic potential sweeps of the two types of manganese chloride containing ionic liquids containing $0.3 \mathrm{M}$ and $0.5 \mathrm{M}$ of the manganese chloride were carried out for comparison. The cathodic polarisation curves are shown 
in Figure 5. It is seen that the curves produced by $\mathrm{MnCl}_{2} \cdot 4 \mathrm{H}_{2} \mathrm{O}$ are different in format to those of $\mathrm{MnCl}_{2} \cdot 4 \mathrm{H}_{2} \mathrm{O}$, indicating that a reduction of moisture was, to some extent, affecting the electrodeposition process in the ionic liquid. This could be due to the moisture in $\mathrm{MnCl}_{2} \cdot 4 \mathrm{H}_{2} \mathrm{O}$ inducing hydrogen evolution. Whilst for $\mathrm{MnCl}_{2} \cdot \mathrm{H}_{2} \mathrm{O}$ it is presumed that little moisture would be present in the electrolyte and therefore the secondary process beginning at ca. $-1.5 \mathrm{~V}$ would most likely be mostly the electrodeposition of manganese. As a result of the moisture effect, the ionic liquid based on $2: 1$ urea/ $\mathrm{ChCl}$ containing $0.4 \mathrm{M}$ $\mathrm{ZnCl}_{2} / 0.7 \mathrm{M} \mathrm{MnCl}_{2} \cdot \mathrm{H}_{2} \mathrm{O}$ was then identified to be the composition of interest in the further investigation of producing $\mathrm{Zn}-\mathrm{Mn}$ by electrodeposition.

\section{Potentiostatic Electrodeposition}

The current-time curves from the electrodeposition of $0.4 \mathrm{M} \mathrm{ZnCl}_{2}+0.7 \mathrm{M}$ $\mathrm{MnCl}_{2} \cdot \mathrm{H}_{2} \mathrm{O}$ in 2:1 urea/ChCl that were obtained at different potentials of -1.0 $\mathrm{V},-1.2 \mathrm{~V},-1.6 \mathrm{~V}$ and $-1.8 \mathrm{~V}$ and at a range of temperatures are plotted and shown in Figures 6-9. As can be seen, at -1.0V there was a very small current which decreased sharply during the first $20 \mathrm{~s}$ for all the temperatures studied. The current then decreased gradually as the time increased to ca. $220 \mathrm{~s}$ and subsequently remained almost constant. There appeared to be no significant electrodeposition occurring at $-1.0 \mathrm{~V}$ for all the temperatures studied and the reaction that produced the currents could be the reduction of oxygen as a cathodic process.

For electrodeposition at $-1.2 \mathrm{~V},-1.6 \mathrm{~V}$ and $-1.8 \mathrm{~V}$, it can be seen that electrodeposition at $20^{\circ} \mathrm{C}$ generally occurred at much lower currents when compared to $40^{\circ} \mathrm{C}$ and $60^{\circ} \mathrm{C}$. Analogous to $-1.0 \mathrm{~V}$, the current decreased significantly in the first $20 \mathrm{~s}$ and then declined steadily as the time increased and subsequently became virtually constant. This could be due to the concentration of depositing ions having become relatively low near the cathode and therefore mass transport became a rate determining process. For the electrodeposition at $-1.8 \mathrm{~V}$ and $60^{\circ} \mathrm{C}$, the current decreased gradually for the $60 \mathrm{~s}$ and then fluctuated as the time increased. This abnormal observation may have been caused by the elevated temperature, which increased electrodeposition producing an electrodeposit which was poorly 
adherent and periodically became detached and then subsequently reformed. This was confirmed on observing the electrodeposits at the end of the experiment. They were found to be powdery and had poor adhesion.

There was no electrodeposit observed on the coupons produced at $20^{\circ} \mathrm{C}$ at both $-1.0 \mathrm{~V}$ and $-1.2 \mathrm{~V}$. However, as the potential was made more negative, i.e. to $-1.6 \mathrm{~V}$ and $-1.8 \mathrm{~V}$, well adhered black electrodeposits were obtained. Analogous to deposition at $20^{\circ} \mathrm{C}$, coupons produced at $40^{\circ} \mathrm{C}$ and $60^{\circ} \mathrm{C}$ at -1.0 $\checkmark$ did not produce any significant electrodeposit. However, at both $40^{\circ} \mathrm{C}$ and $60^{\circ} \mathrm{C}$, thin layers of bright silver coloured deposits started to form as the applied potential was lowered to $-1.2 \mathrm{~V}$. Figure 10 illustrates current-time trends for a greater range of potentials at $40^{\circ} \mathrm{C}$. As the potential was made more negative to $-1.3 \mathrm{~V},-1.4 \mathrm{~V}$ and $-1.5 \mathrm{~V}$, the deposits obtained became darker. It was believed that the silver coloured deposits obtained at $-1.2 \mathrm{~V}$ and $-1.3 \vee$ were likely to be zinc whilst manganese may well begin to deposit at $-1.4 \mathrm{~V}$ or $-1.5 \mathrm{~V}$. This is due to the fact that the equilibrium electrode potential of zinc is more noble than that of manganese and therefore zinc was believed to be deposited preferentially whilst manganese only started to deposit when the electrode potential had lowered to a sufficiently negative value. Moreover, from the cathodic polarisation curves for $\mathrm{MnCl}_{2} \cdot \mathrm{H}_{2} \mathrm{O}$ (Figure 5), it seemed evident that manganese electrodeposition was likely to commence at ca. $-1.5 \mathrm{~V}$; it was therefore believed that in agreement with the cathodic polarisation curves, deposits obtained at $-1.4 \mathrm{~V}$ and $-1.5 \mathrm{~V}$ probably contained some manganese. At $-1.6 \mathrm{~V}$, for both $40^{\circ} \mathrm{C}$ and $60^{\circ} \mathrm{C}$, black and smooth adherent deposits were obtained and subsequently at $-1.8 \mathrm{~V}$, the 
resulting deposits, however, were rougher and powdery. The deposits formed at -1.6 $\mathrm{V}$ and $-1.8 \mathrm{~V}$ were probably an alloy electrodeposit of $\mathrm{Zn}-\mathrm{Mn}$. Generally, from the electrodeposits obtained at $40^{\circ} \mathrm{C}$, it was observed that cathodic potentials ranging from $-1.3 \mathrm{~V}$ to $-1.6 \mathrm{~V}$ produced quite dense and well adhered deposits. Reducing the potential, however, led to an increasing current but subsequently resulted in relatively poor adherence of the deposits.

The use of addition agents to the zinc-manganese bath was also investigated at this stage. $0.4 \mathrm{M}$ and $0.8 \mathrm{M} \mathrm{H} \mathrm{H}_{3} \mathrm{BO}_{3}$ were added respectively into 2:1

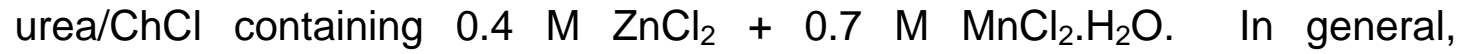
electrodeposition with $0.4 \mathrm{M}$ and $0.8 \mathrm{M} \mathrm{H}_{3} \mathrm{BO}_{3}$ had comparable current-time curves. Those from an electrolyte containing $0.4 \mathrm{M}$ are shown in Figure 11. Although the general current-time trends were similar with the addition agent present, the electrodeposition current in general was significantly increased. On the other hand, further increasing the concentration of $\mathrm{H}_{3} \mathrm{BO}_{3}$ did not actually increase the current. In fact, electrodeposition was observed to occur at analogous currents for both $0.4 \mathrm{M}$ and $0.8 \mathrm{M} \mathrm{H}_{3} \mathrm{BO}_{3}$ at $-1.0 \mathrm{~V},-1.2 \mathrm{~V}$ and 1.4 V. Conversely, electrodeposition from $0.4 \mathrm{M} \mathrm{H}_{3} \mathrm{BO}_{3}$ occurred, generally, at higher currents when compared with the electrolyte containing $0.8 \mathrm{M} \mathrm{H}_{3} \mathrm{BO}_{3}$ at cathodic potentials ranging from $-1.5 \mathrm{~V}$ to $-1.8 \mathrm{~V}$.

From visual observation of the coupons produced from the ionic liquid containing $0.4 \mathrm{M} \mathrm{H}_{3} \mathrm{BO}_{3}$ at $40^{\circ} \mathrm{C}$ the electrolyte began to produce dull silver coloured deposits at $-1.2 \mathrm{~V}$ then the deposits started to be getting darker and denser at $-1.4 \mathrm{~V}$ and $-1.5 \mathrm{~V}$ with black colour constituents deposited at the edges, which were the high current density areas on the coupons. The deposits were well adhered. The black coloured deposits could be manganese or 'burnt' zinc. The zinc electrodeposition might have reached its limiting current when the potential was made more negative and thus resulting in burnt deposits. It was reported by Sylla et al [16] that from an aqueous acidic bath containing $0.4 \mathrm{M} \mathrm{H}_{3} \mathrm{BO}_{3}$ at room temperature, zinc was deposited between $-1.1 \mathrm{~V}$ and $-1.4 \mathrm{~V} / \mathrm{SCE}$ whilst manganese was deposited at potential lower or equal to $-1.5 \mathrm{~V} / \mathrm{SCE}$. As the potential was reduced to $-1.6 \mathrm{~V}$, the 
deposits obtained became noncoherent, dark, rough and powdery as well as having a burnt appearance. This could be due to the more negative potential which had induced the process to reach its limiting current density and therefore led to poor deposits. As a result, as the potentials were made still more negative to $-1.7 \mathrm{~V}$ and $-1.8 \mathrm{~V}$, the deposits obtained, as expected, were powdery and had a burnt appearance.

For electrodeposits obtained from electrolytes with $0.8 \mathrm{M} \mathrm{H}_{3} \mathrm{BO}_{3}$ in $2: 1$ urea/ $\mathrm{ChCl}$ containing $0.4 \mathrm{M} \mathrm{ZnCl}_{2} / 0.7 \mathrm{M} \mathrm{MnCl}_{2} \cdot \mathrm{H}_{2} \mathrm{O}$ at $40^{\circ} \mathrm{C}$, it was apparent that the deposits obtained at $-1.2 \mathrm{~V}$ and $-1.4 \mathrm{~V}$ were analogous to those obtained from electrolytes containing $0.4 \mathrm{M} \mathrm{H}_{3} \mathrm{BO}_{3}$ at the same potentials and temperatures. In contrast, at the potentials of $-1.5 \mathrm{~V}$ and $-1.6 \mathrm{~V}$, black and well adherent deposits were obtained, unlike those obtained from $0.4 \mathrm{M} \mathrm{H}_{3} \mathrm{BO}_{3}$, at which the deposits were dark silver and powdery at $-1.5 \mathrm{~V}$ and $-1.6 \mathrm{~V}$. Hence, it was believed that by increasing the concentration levels of $\mathrm{H}_{3} \mathrm{BO}_{3}$ had improved the electrodeposition process. This is in agreement with the currenttime data produced from both electrolytes, in which the $0.8 \mathrm{M} \mathrm{H}_{3} \mathrm{BO}_{3}$ containing electrolytes, in general, had lower currents than those of $0.4 \mathrm{M}$ $\mathrm{H}_{3} \mathrm{BO}_{3}$ from $-1.5 \mathrm{~V}$ to $-1.8 \mathrm{~V}$. As a result, electrodeposition from $0.8 \mathrm{M} \mathrm{H}_{3} \mathrm{BO}_{3}$ containing electrolytes may not have reached the limiting current density even when the potential was lowered to $-1.6 \mathrm{~V}$. Nevertheless, burnt deposits had been obtained as the potential was made more negative, i.e. at $-1.7 \mathrm{~V}$ and $1.8 \mathrm{~V}$. The deposits obtained at $-1.8 \mathrm{~V}$ were, however, more adherent than those obtained from $0.4 \mathrm{M} \mathrm{H}_{3} \mathrm{BO}_{3}$ containing electrolytes.

From the visual observation, $0.8 \mathrm{M} \mathrm{H}_{3} \mathrm{BO}_{3}$ containing electrolytes tended to produce more adherent deposits when compared to $0.4 \mathrm{M} \mathrm{H}_{3} \mathrm{BO}_{3}$. However, scanning electron microscopy (SEM) was carried out to determine the morphology, the elements contained in the deposits as well as the threshold potential value corresponding to the electrodeposition of manganese.

\section{Morphology and Manganese Content}

Fig 12 illustrates electrodeposits obtained from $0.4 \mathrm{M} \mathrm{ZnCl} 2+0.7 \mathrm{M} \mathrm{MnCl}_{2} \cdot \mathrm{H}_{2} \mathrm{O}$ in $2: 1$ urea $/ \mathrm{ChCl}$ at $40^{\circ} \mathrm{C}$, their morphologies and manganese contents. Zinc began to deposit at $-1.2 \mathrm{~V}$ (not shown) and the thickness increased gradually 
as the potential was made more negative. At $-1.4 \mathrm{~V}$ no manganese was evident and the zinc-containing deposits consisted of small crystallites. Small amounts of manganese were then observed at $-1.5 \mathrm{~V}$ and $-1.6 \mathrm{~V}$ with slightly finer crystallites dispersed on the surface of the deposits. The manganese content obtained at $-1.5 \mathrm{~V}$ was slightly higher than that of $-1.6 \mathrm{~V}$ and the crystallites were also a little larger. As the potential was lowered to $-1.8 \mathrm{~V}$, the manganese content increased significantly to approximately 34 wt.\% (this value has been recalculated by not taking into account of copper) whilst the grain size of the nodular crystallites had increased as well. Therefore, it could be presumed that the higher manganese content induced the growth of crystallites. Similar crystallites have been reported by Chen and Hussey [14] for Zn-Mn deposits prepared in tri-1-butylmenthylammonium bis((trifluoromethane)sulfonyl)imide ionic liquid. In addition, it is clearly seen that cracks, which had also been observed by visual observation, had formed on the deposits. However, the copper substrate signal was still high even when the potential was $-1.8 \mathrm{~V}$. This could be due to the fact that the electrodeposition time was short, resulting in porosity and/or a very thin deposit.

A 2:1 urea/ChCl containing $0.4 \mathrm{M} \mathrm{ZnCl}_{2}+0.7 \mathrm{M} \mathrm{MnCl}_{2} \cdot \mathrm{H}_{2} \mathrm{O}$ ionic liquids with the addition of $0.4 \mathrm{M} \mathrm{H}_{3} \mathrm{BO}_{3}$ started to produce pure zinc deposits at $-1.2 \mathrm{~V}$. No manganese was found at $-1.2 \mathrm{~V}$ and the morphology (Figure 13) shows that fine crystallites were formed uniformly. Small amounts of manganese started to deposit at $-1.4 \mathrm{~V}$ and $-1.5 \mathrm{~V}$. The SEM micrograph of the deposit obtained at -1.4 $\mathrm{V}$ illustrates that larger crystals with hexagonal symmetry were dispersing evenly. Deposits obtained at $-1.5 \mathrm{~V}$ had similar morphology (not shown) as the one obtained at $-1.4 \mathrm{~V}$. Whilst at $-1.6 \mathrm{~V}$, oxygen started to be detected in the deposits. This could be due to the burnt deposits containing oxides / hydroxides from the electrodeposition process or the coating surface might have formed oxides prior to analysis when significant Mn content was present. The crystals formed a hexagonal flower-type morphology and this was believed to be the result of the increasing Mn content, which was 23.3 wt.\%. The morphology obtained at $-1.6 \mathrm{~V}$, as well as the Mn content obtained at $-1.7 \mathrm{~V}$, was similar to those obtained from the electrolyte without the 
addition agent at $-1.8 \mathrm{~V}$. As a consequence, it was presumed that the addition of $\mathrm{H}_{3} \mathrm{BO}_{3}$ had promoted the growth of crystallites as well as the deposition of manganese at a less negative potential. Similar cauliflower-type morphology but with less manganese content was reported by Sylla et al [77] for Zn-Mn alloys obtained from an aqueous acidic bath containing $0.4 \mathrm{M} \mathrm{H}_{3} \mathrm{BO}_{3}$.

Similar observations were apparent for the electrodeposition of $0.4 \mathrm{M}$ $\mathrm{ZnCl}_{2}+0.7 \mathrm{M}+\mathrm{MnCl}_{2} \cdot \mathrm{H}_{2} \mathrm{O}+0.8 \mathrm{M} \mathrm{H}_{3} \mathrm{BO}_{3}$ in $2: 1$ urea/ChCl at $40^{\circ} \mathrm{C}$, i.e. zinc deposits started to occur at $-1.2 \mathrm{~V}$ (not shown). A similar morphology, as shown in Figure 14, was obtained at $-1.4 \mathrm{~V}$ as to that from the ionic liquid electrolyte containing $0.4 \mathrm{M} \mathrm{H}_{3} \mathrm{BO}_{3}$. Manganese-containing deposits, however, were not obtained at this potential. At $-1.5 \mathrm{~V}, 21.8 \mathrm{wt}$ \% of manganese was obtained with a finely dispersed acicular morphology, which was believed could be induced by the higher concentration of $\mathrm{H}_{3} \mathrm{BO}_{3}$. The Mn content at 1.6 $\mathrm{V}$ was lower than that of $-1.5 \mathrm{~V}$. Nevertheless, it was clearly observed that the crystals tended to grow more dendritically at higher Mn content. Oxygen began to be detected at $-1.5 \mathrm{~V}$ but its presence has been omitted from the analysis. The dendritic crystals grew continuously as the potential was made more negative and their size increased substantially as the potential was reduced to $-1.8 \mathrm{~V}$. Cracks were again evident at $-1.7 \mathrm{~V}$ and $-1.8 \mathrm{~V}$. It was once again noted that $-1.7 \mathrm{~V}$ produced slightly higher levels of manganese than $-1.8 \mathrm{~V}$. This could be the fact that more manganese appeared in oxide form at $-1.7 \mathrm{~V}$ or the deposition of manganese started to decline as the potential was made more negative with addition of higher concentration of $\mathrm{H}_{3} \mathrm{BO}_{3}$.

\section{CONCLUSIONS}

The initial characterisations of ionic liquids containing different concentration levels of $\mathrm{ZnCl}_{2}$ and $\mathrm{MnCl}_{2} \cdot 4 \mathrm{H}_{2} \mathrm{O}$ suggested that viscosities of the ionic liquids decreased significantly as the temperatures increased. Viscosity values were significantly higher than aqueous electrolytes. Conductivities of ionic liquid 
electrolytes increased with increasing temperatures. Conductivities were significantly lower than aqueous electrolytes. Ionic liquid of $2: 1$ urea/ChCl containing $0.4 \mathrm{M} \mathrm{ZnCl} / 0.7 \mathrm{M} \mathrm{MnCl}_{2} .4 \mathrm{H}_{2} \mathrm{O}$ was identified to be the composition of interest for performing electrodeposition of $\mathrm{Zn}-\mathrm{Mn}$ alloy.

$\mathrm{MnCl}_{2} \cdot 4 \mathrm{H}_{2} \mathrm{O}$ was converted to $\mathrm{MnCl}_{2} \cdot \mathrm{H}_{2} \mathrm{O}$ by heat treatment since moisture could influence the effectiveness of the electrodeposition of $\mathrm{Zn}-\mathrm{Mn}$ from the ionic liquids.

Cathodic polarisation measurements of ionic liquids containing solely $\mathrm{ZnCl}_{2}$ and $\mathrm{MnCl}_{2} \cdot \mathrm{H}_{2} \mathrm{O}$ suggested that electrodeposition of zinc and manganese were likely to commence at ca. $-1.0 \mathrm{~V}$ and $-1.5 \mathrm{~V}$ respectively. The current-time curves, obtained through potentiostatic electrodeposition measurements, suggested that as the potential was made more negative, the electrodeposition current increased correspondingly. Furthermore, as the temperatures increased, the deposition current increased as well. The addition agent, $\mathrm{H}_{3} \mathrm{BO}_{3}$ also increased the electrodeposition current.

Potentiostatic electrodeposition conducted with $2: 1$ urea/ChCl containing $0.4 \mathrm{M}$ $\mathrm{ZnCl}_{2}+0.7 \mathrm{M} \mathrm{MnCl}_{2} \cdot \mathrm{H}_{2} \mathrm{O}$ with and without the addition agent, $\mathrm{H}_{3} \mathrm{BO}_{3}$, at $40^{\circ} \mathrm{C}$ produced significant differences in the deposits obtained. Without the addition agent, powdery deposits were obtained at more negative potentials. The addition agents increased the level of manganese deposition but also the formation of dendrites. Increasing the concentration of $\mathrm{H}_{3} \mathrm{BO}_{3}$ did not actually increase the manganese content significantly but in fact contributed to avoiding the deposition of powdery deposits at less negative potentials. Increasing the electrodeposition temperatures from $40^{\circ} \mathrm{C}$ to $60^{\circ} \mathrm{C}$, however, produced powdery deposits which did not contain significantly more manganese.

For all the electrolytes studied, pure zinc deposition commenced at around $1.2 \mathrm{~V}$ and increased as the potential was made more negative. Manganese content increased as the electrodeposition potential was made more negative but powdery deposits were obtained when the electrodeposition was believed to be reaching its limiting current density at more negative potentials. Smooth and adherent alloy electrodeposits of $\mathrm{Zn}-\mathrm{Mn}$ were commonly obtained at -1.5 
$\mathrm{V}$ and $40^{\circ} \mathrm{C}$ from electrolytes with and without $\mathrm{H}_{3} \mathrm{BO}_{3}$. At this potential ionic liquid of $2: 1$ urea/ChCl containing $0.4 \mathrm{M} \mathrm{ZnCl} 2+0.7 \mathrm{M} \mathrm{MnCl}_{2} \cdot \mathrm{H}_{2} \mathrm{O}$ produced deposits with a manganese content of approximately 8 wt.\%. However, deposits containing less manganese (2 wt. \%) were obtained from ionic liquids containing $0.4 \mathrm{M} \mathrm{H}_{3} \mathrm{BO}_{3}$. Whilst with the addition of $0.8 \mathrm{M} \mathrm{H} \mathrm{H}_{3} \mathrm{BO}$, well adherent deposits containing 22 wt.\% of manganese were obtained.

\section{REFERENCES}

1. F. A. Lowenheim, "Electroplating", McGraw-Hill Book Co, New York, 1978.

2. D. R. Gabe, "Principles of Metal Surface Treatment and Protection", 3rd Ed., Merlin Books Ltd, Devon, 1993.

3. H. G. Todt, Trans. Inst. Met. Finish. 5191 (1973).

4. G.D.Wilcox and D.R.Gabe, Corros. Sci. $\underline{35}, 1251$ (1993).

5. M. Sagiyama, T. Urakawa, T. Adaniya and T. Hara, SAE Tech. Paper 860, 268 (1986).

6. G. Govindarajan, V. Ramakrishnan, S. Ramamurthi, V. Subramaniam and N. V. Parthasaradhy, B. Electrochem. $\underline{5} 352$ (1989).

7. D. R. Gabe, G. D. Wilcox, A. Jamani and B. P. Pearson, Met. Finish. 91(8) 34 (1993)

8. A. Brenner, Electrodeposition of Alloys: Principles and Practice, Academic Press, New York, 1963.

9. G. D. Wilcox and B. Petersen, Trans. Inst. Met. Finish. 74115 (1996).

10. F. Endres and S. Z. Abedin, Phys. Chem. Chem. Phys. $\underline{8} 2101$ (2006).

11. F. Endres, Z. Phys. Chem. 218255 (2004).

12. A. P. Abbott, G. Capper, D. L. Davies, R. K. Rasheed and V. Tambyrajah, Chem. Commun. 70 (2003).

13. A. P. Abbott, G. Capper, K. J. McKenzie and K. S. Ryder, J. Electroanal. Chem. $\underline{599} 288$ (2007).

14. P. Y Chen and C. L Hussey, Electrochim. Acta $\underline{52} 1857$ (2007). Limited, West Sussex, 1990.

15. R.D.Harrison (Edt), Book of Data, Nuffield Advanced Science, Longman Group, London 1972.

16. D. Sylla, C. Rebere, M. Gadouleau, C. Savall, J. Creus and Ph. Refait, J. Appl. Electrochem. 351133 (2005). 


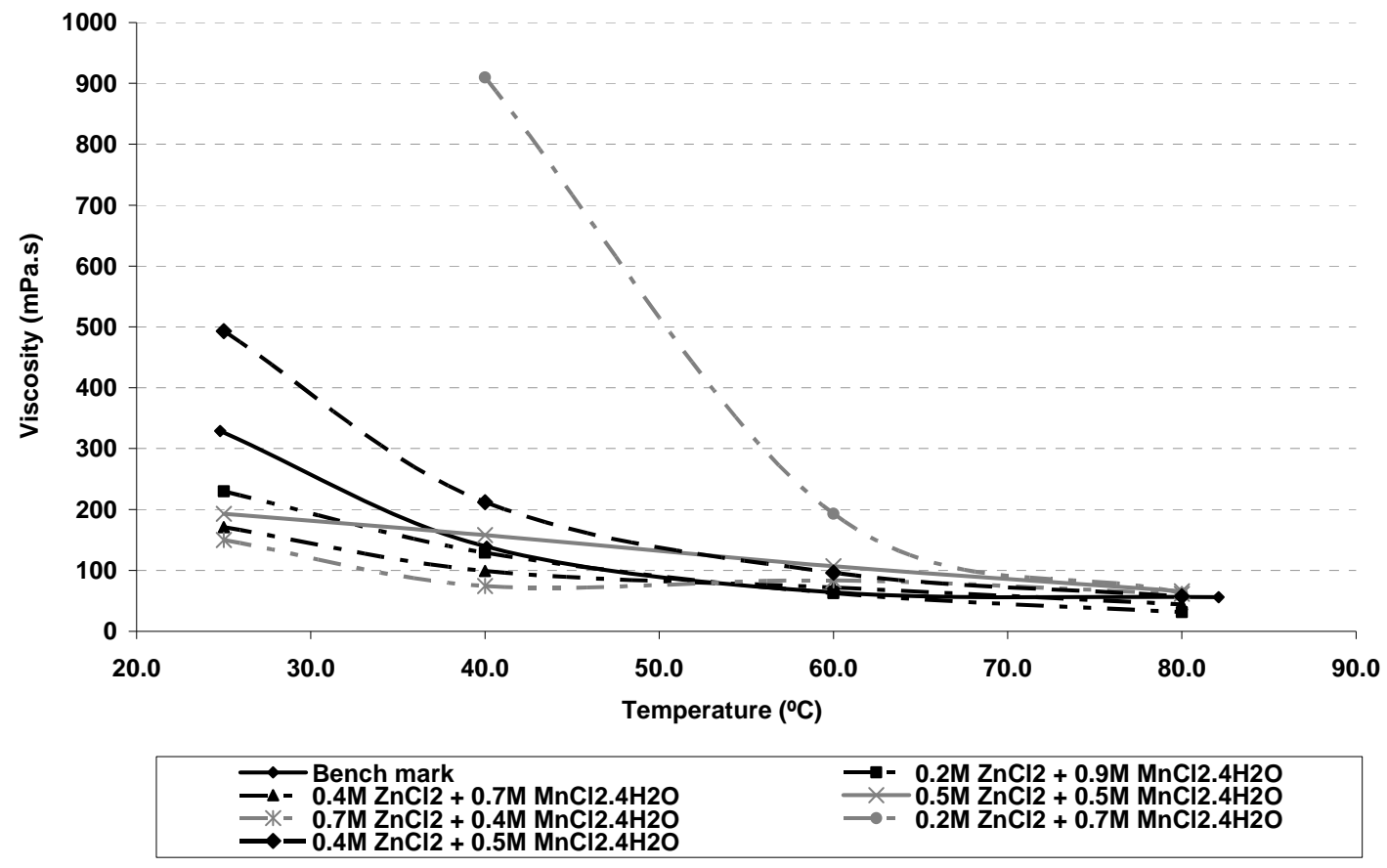

Figure 1 Viscosity of 2:1 urea/ChCl containing $\mathrm{ZnCl}_{2}$ and $\mathrm{MnCl}_{2} \cdot 4 \mathrm{H}_{2} \mathrm{O}$ as a function of temperature and composition. 


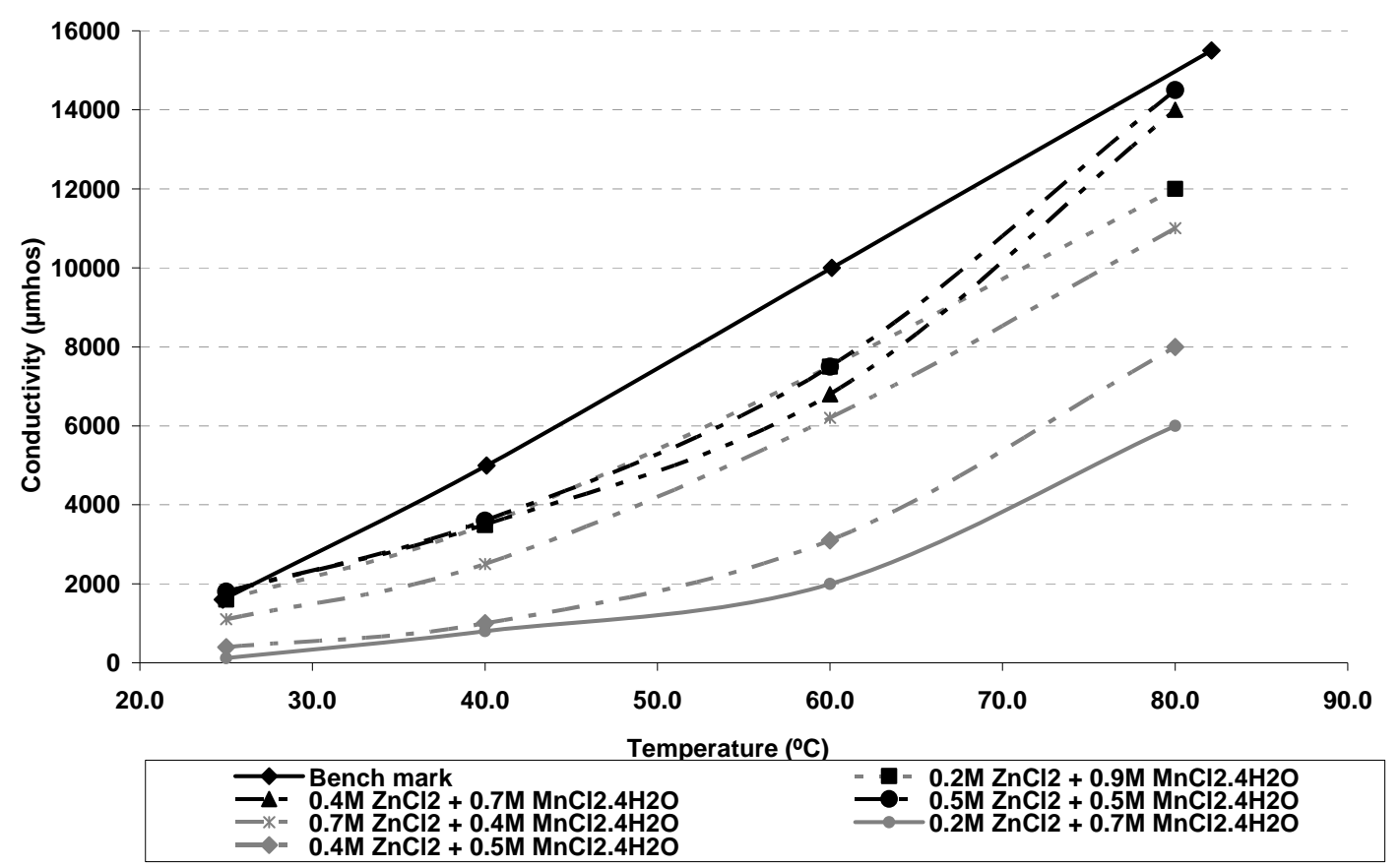

Figure 2 Conductivity of 2:1 urea/ChCl containing $\mathrm{ZnCl}_{2}$ and $\mathrm{MnCl}_{2} \cdot 4 \mathrm{H}_{2} \mathrm{O}$ as a function of temperature and composition. 


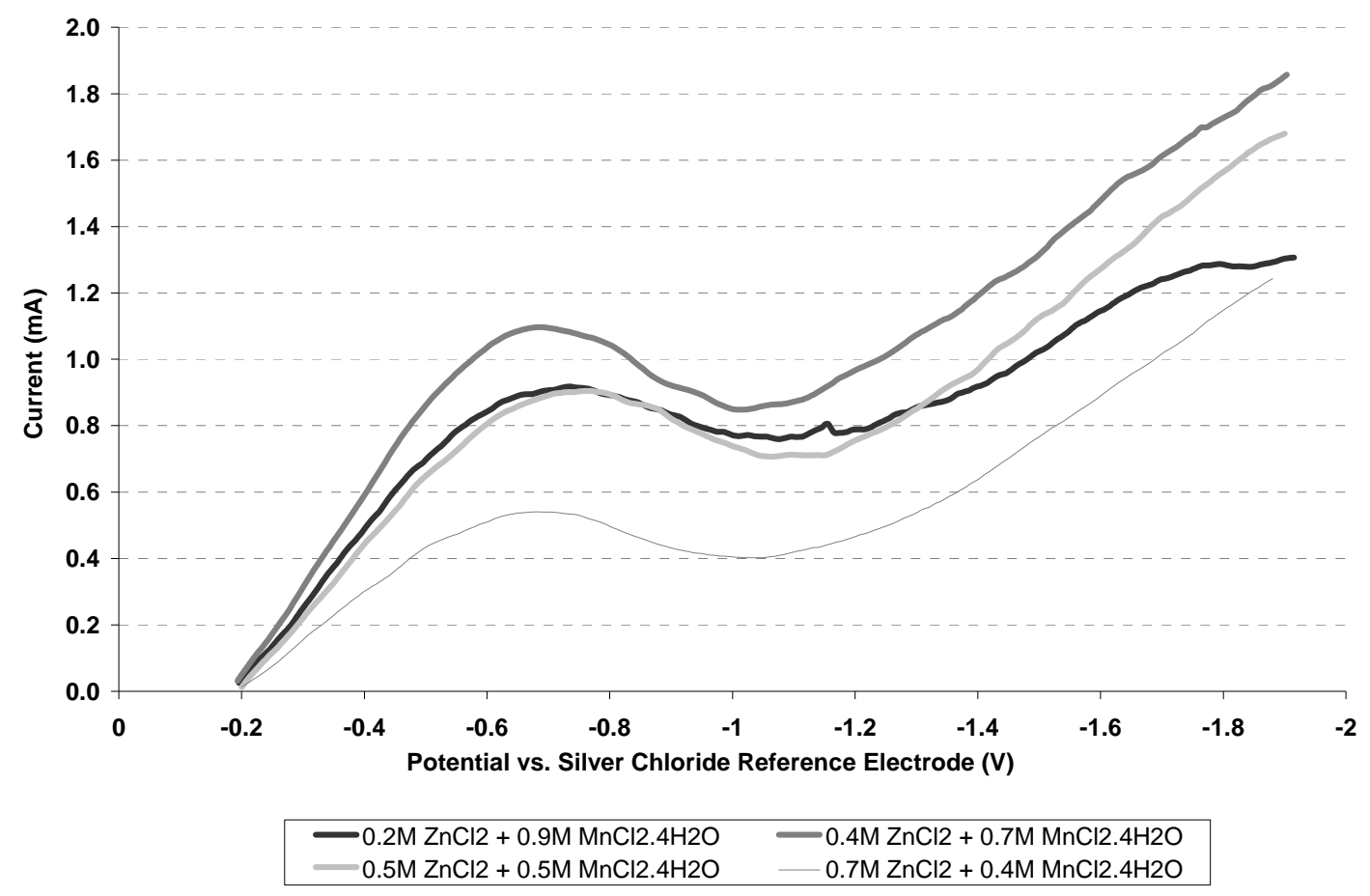

Figure 3 Cathodic polarisation curve of $2: 1$ urea/ $\mathrm{ChCl}$ containing $\mathrm{ZnCl}_{2}$ and $\mathrm{MnCl}_{2} \cdot 4 \mathrm{H}_{2} \mathrm{O}$ as a function of potential and composition. 


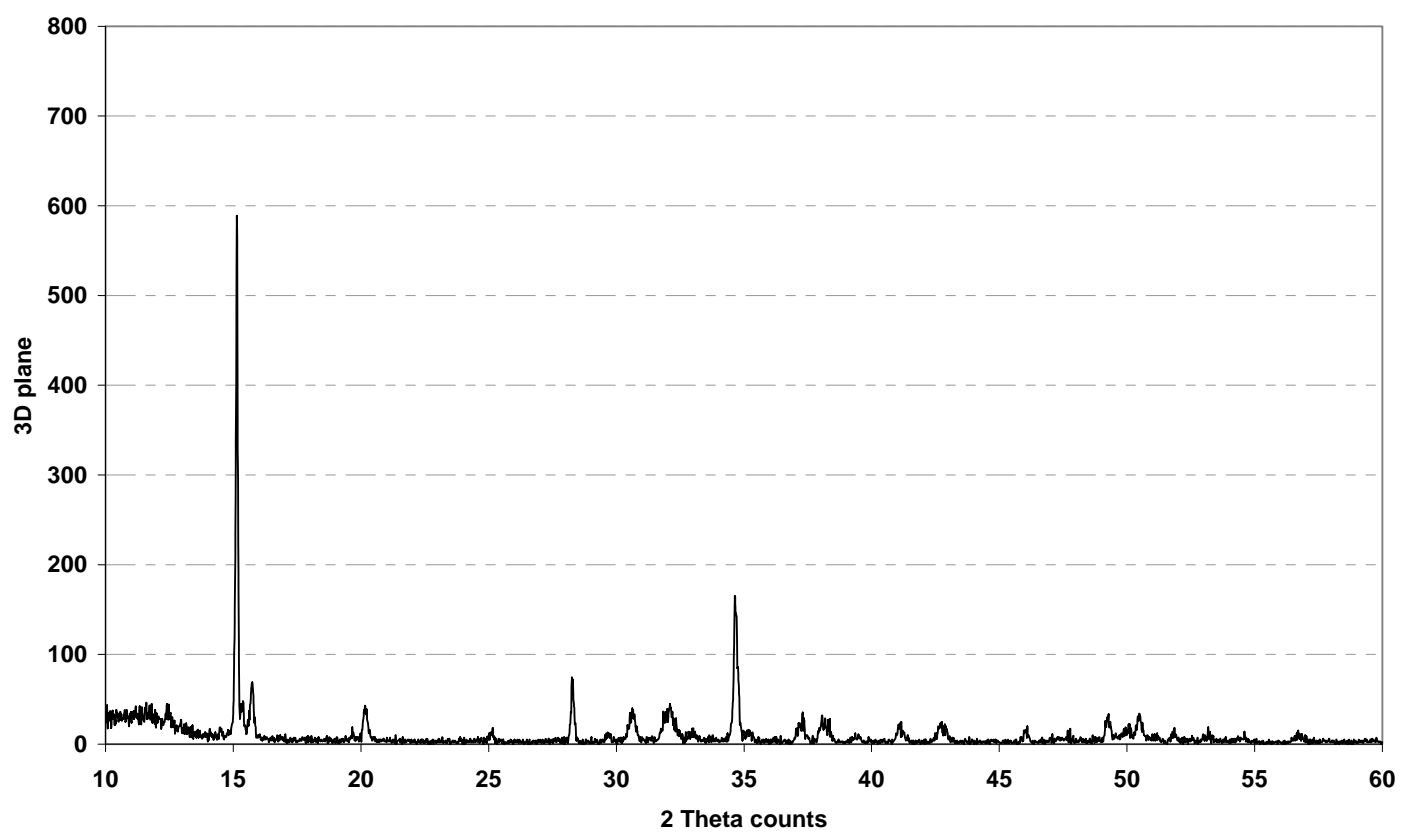

Figure 4 - Diffraction pattern of mono-hydrated manganese chloride, produced from hydrated manganese chloride 


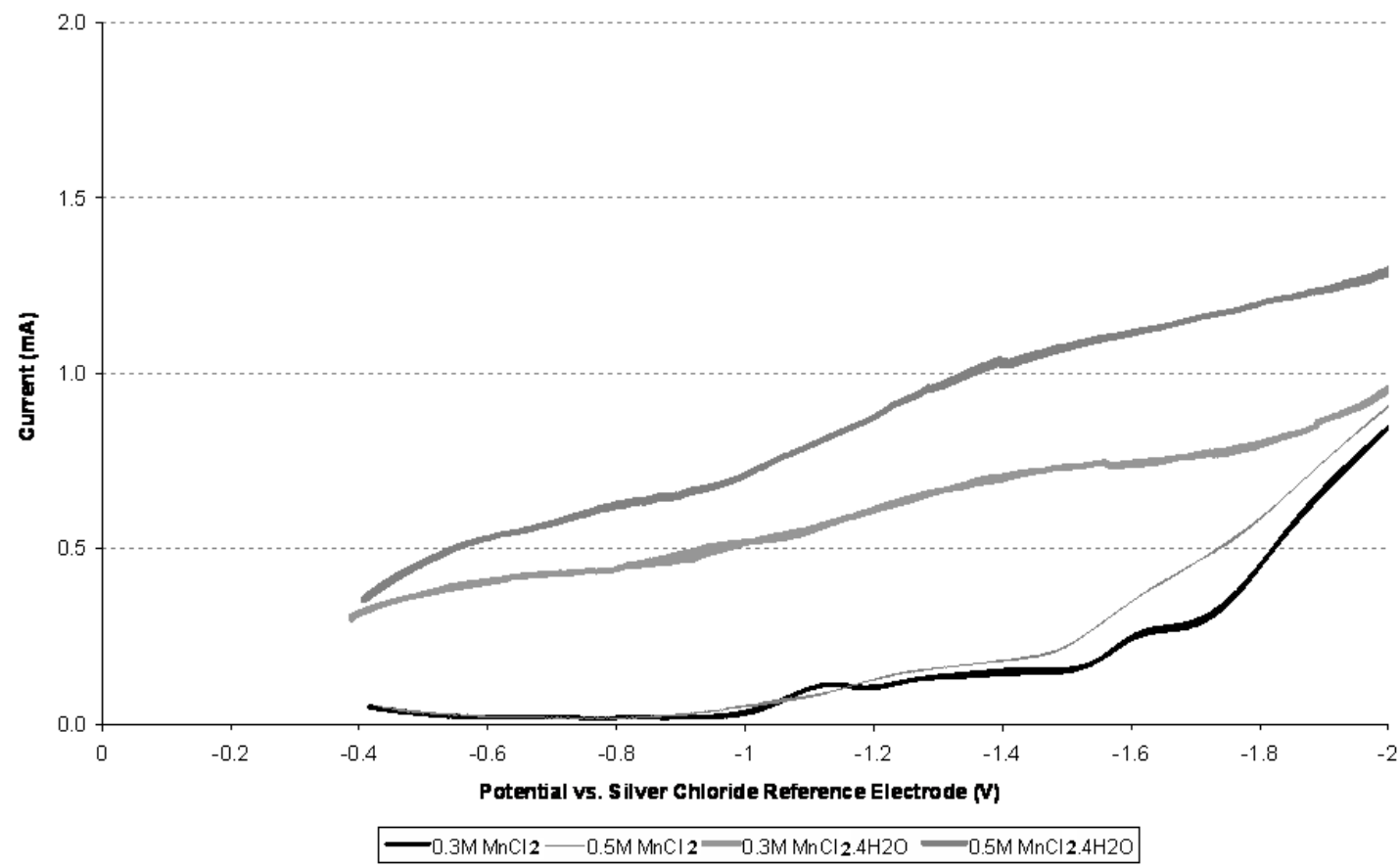

Figure 5 Cathodic polarisation of 2:1 urea/ChCl containing $\mathrm{MnCl}_{2} \cdot \mathrm{H}_{2} \mathrm{O}$ and $\mathrm{MnCl}_{2} .4 \mathrm{H}_{2} \mathrm{O}$ as a function of potential and composition. 


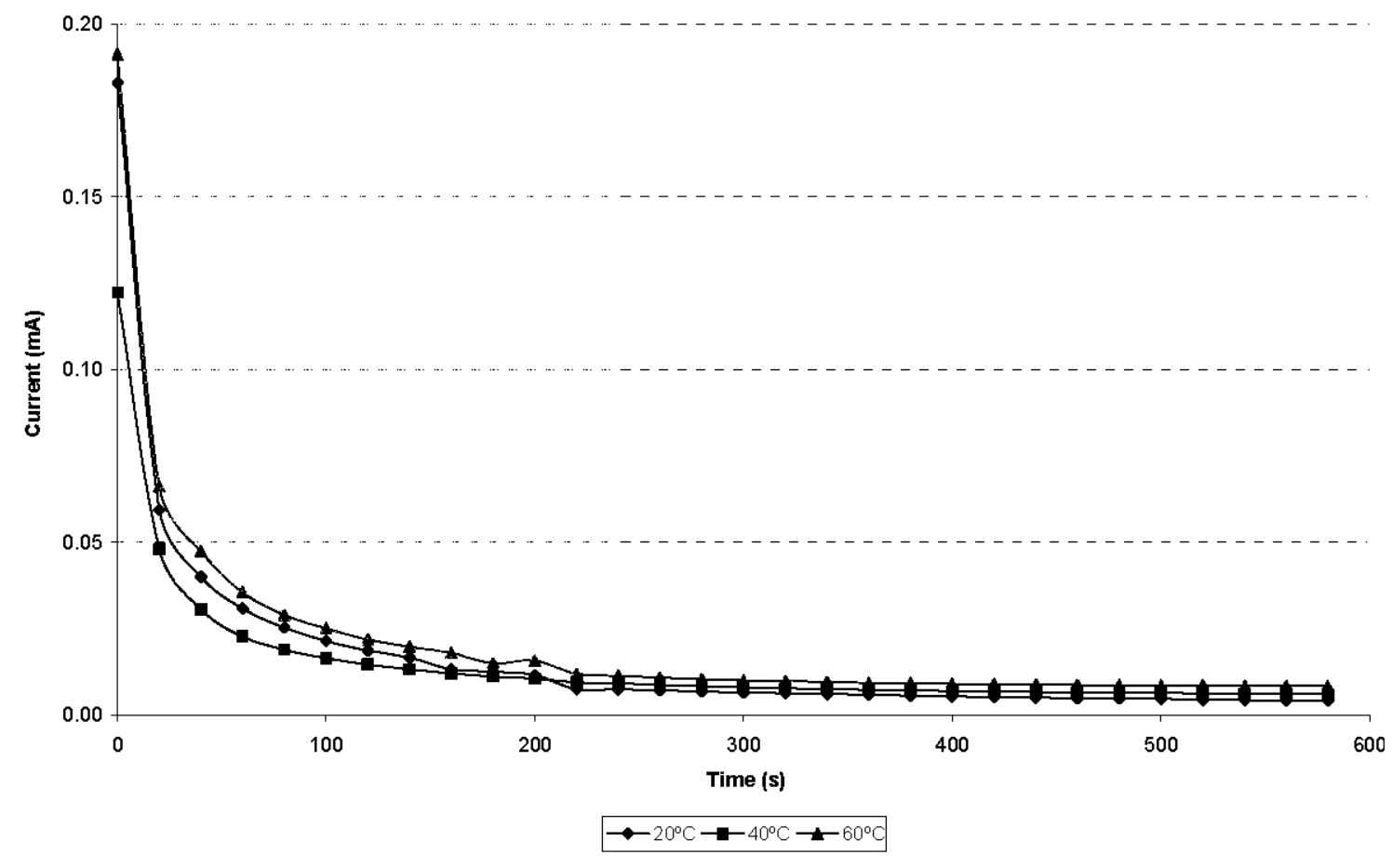

Figure 6 Current-time curves for the deposition of $\mathrm{Zn}-\mathrm{Mn}$ alloys from $0.4 \mathrm{M}$ $\mathrm{ZnCl}_{2} / 0.7 \mathrm{M} \mathrm{MnCl} \cdot \mathrm{H}_{2} \mathrm{O}$ in $2: 1$ urea/ChCl at a potential of $-1.0 \mathrm{~V}$ and temperatures of $20^{\circ} \mathrm{C}, 40^{\circ} \mathrm{C}$ and $60^{\circ} \mathrm{C}$. 


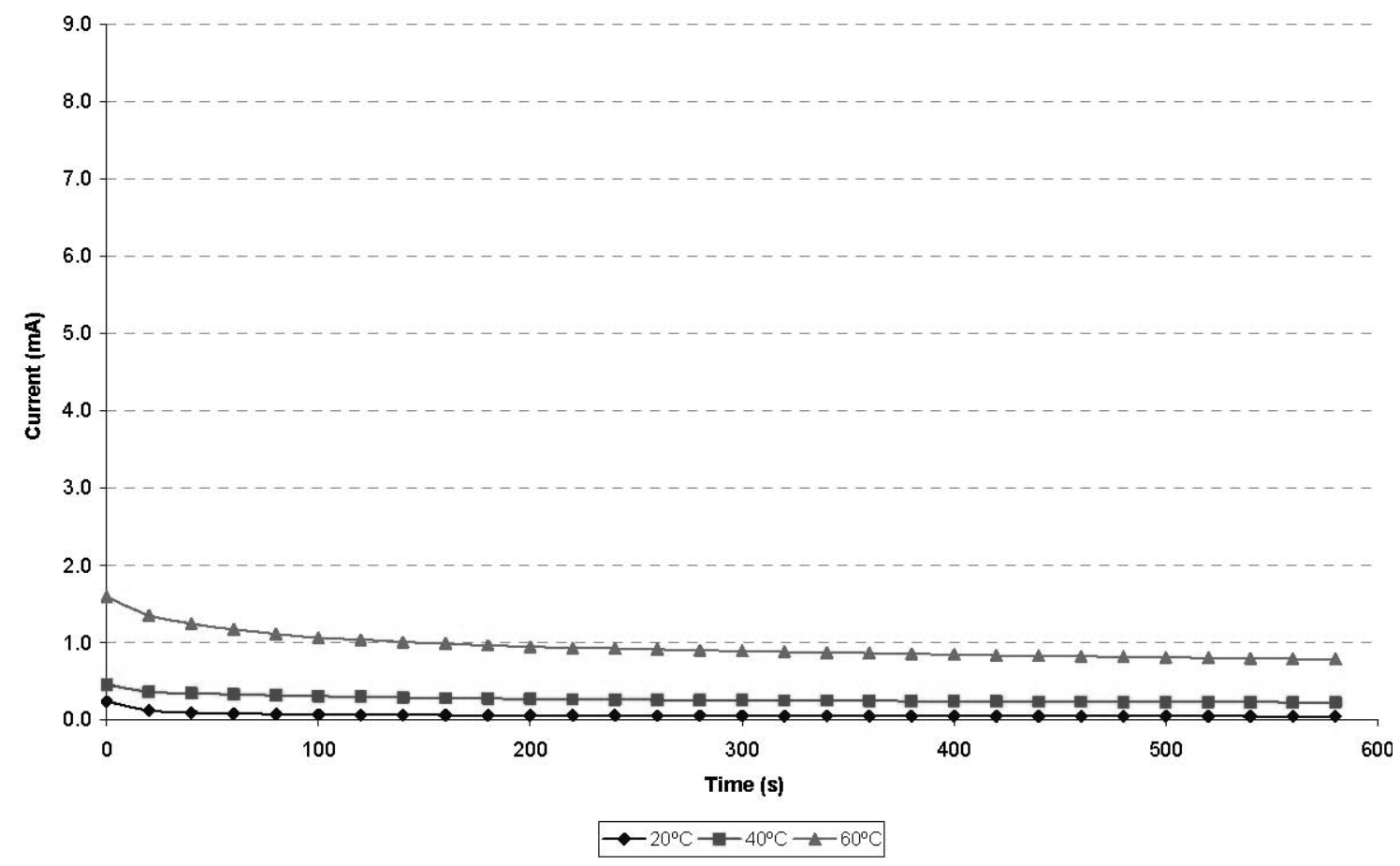

Figure 7 Current-time curves for the deposition of $\mathrm{Zn}-\mathrm{Mn}$ alloys from $0.4 \mathrm{M}$ $\mathrm{ZnCl}_{2} / 0.7 \mathrm{M} \mathrm{MnCl} \cdot \mathrm{H}_{2} \mathrm{O}$ in $2: 1$ urea/ChCl at a potential of $-1.2 \mathrm{~V}$ and temperatures of $20^{\circ} \mathrm{C}, 40^{\circ} \mathrm{C}$ and $60^{\circ} \mathrm{C}$. 


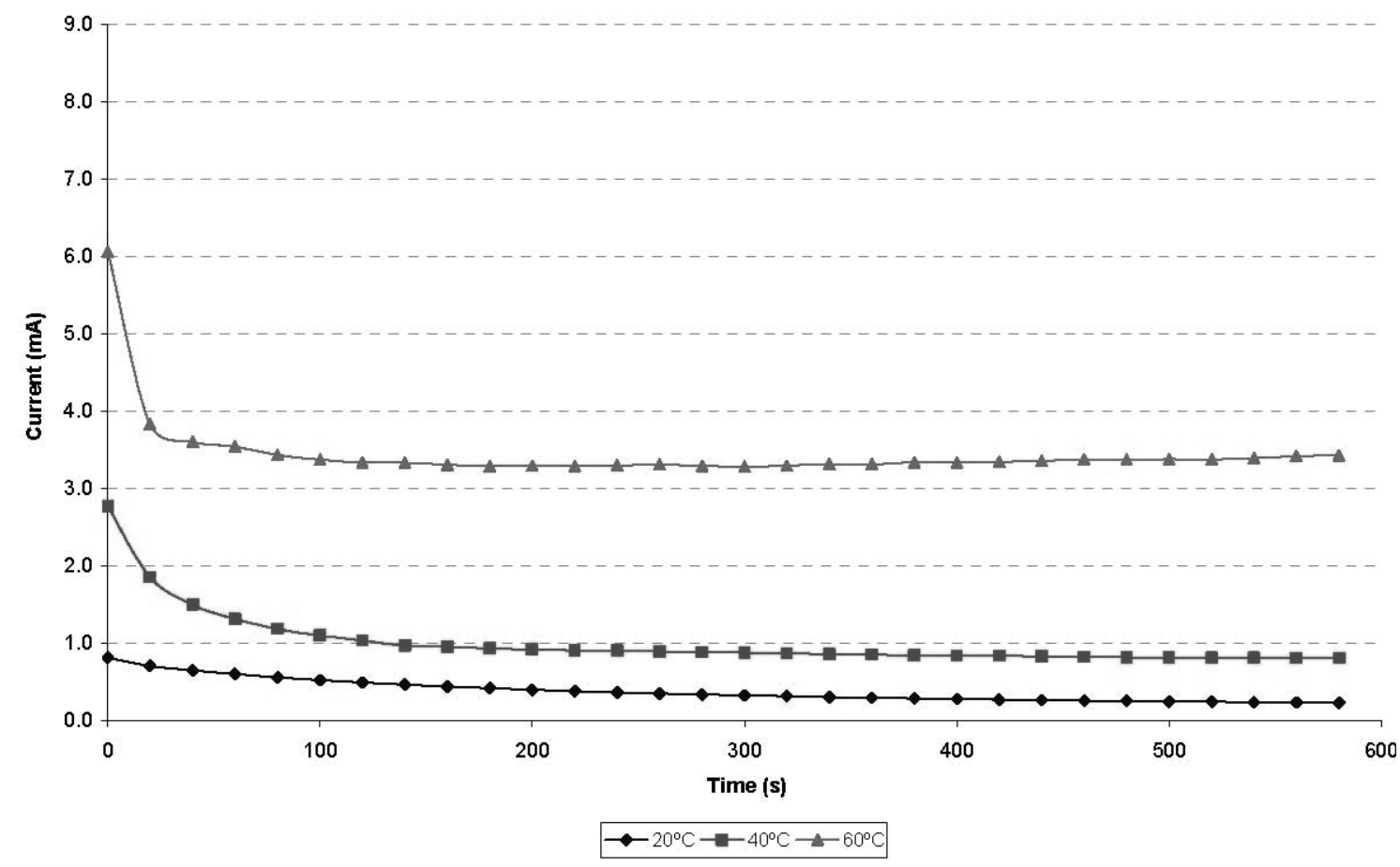

Figure 8 Current-time curves for the deposition of $\mathrm{Zn}-\mathrm{Mn}$ alloys from $0.4 \mathrm{M}$ $\mathrm{ZnCl}_{2} / 0.7 \mathrm{M} \mathrm{MnCl} \cdot \mathrm{H}_{2} \mathrm{O}$ in $2: 1$ urea/ChCl at a potential of $-1.6 \mathrm{~V}$ and temperatures of $20^{\circ} \mathrm{C}, 40^{\circ} \mathrm{C}$ and $60^{\circ} \mathrm{C}$. 


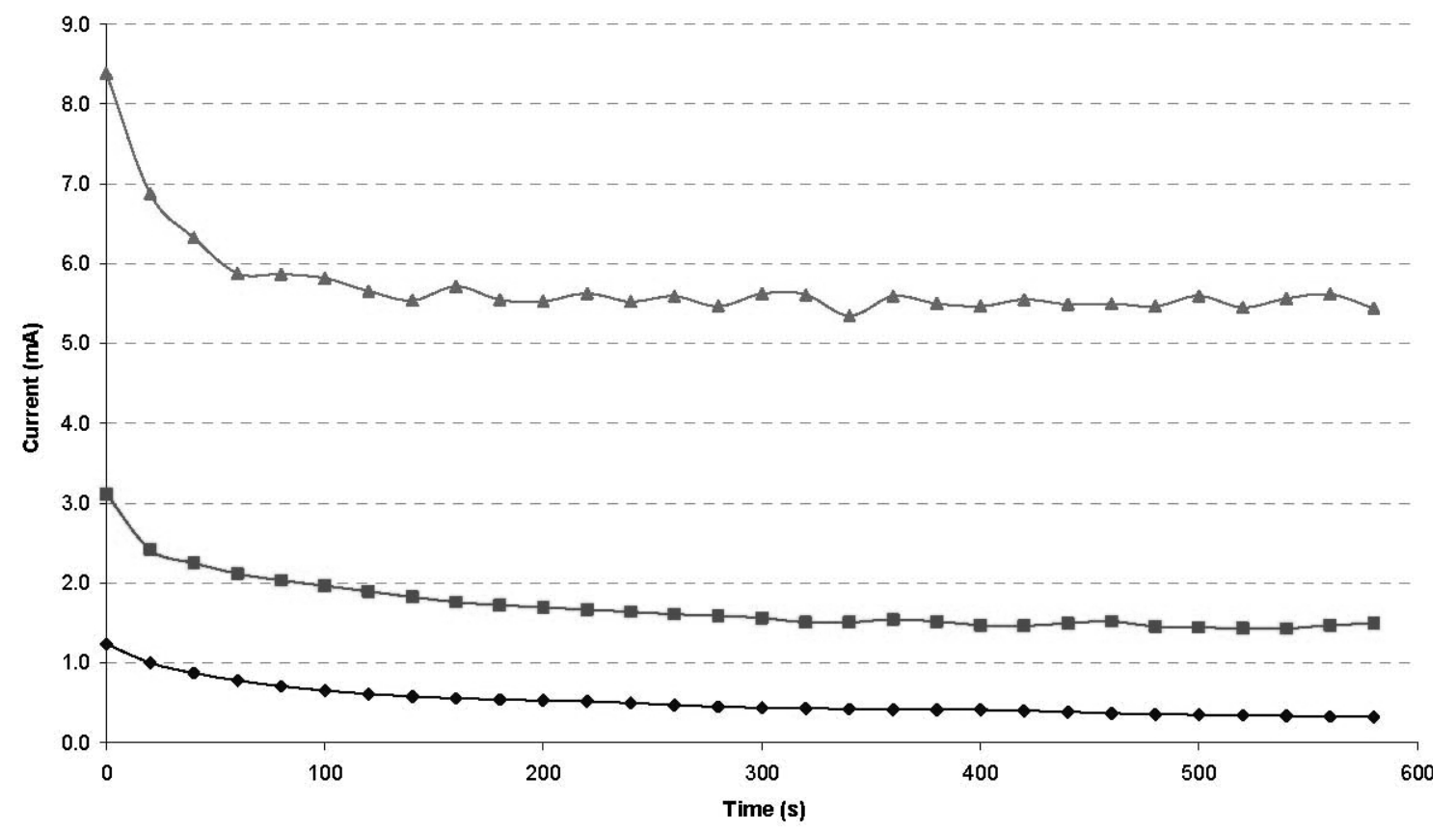

$\rightarrow-20^{\circ} \mathrm{C} \rightarrow-40^{\circ} \mathrm{C} \rightarrow-60^{\circ} \mathrm{C}$

Figure 9 Current-time curves for the deposition of $\mathrm{Zn}-\mathrm{Mn}$ alloys from $0.4 \mathrm{M}$ $\mathrm{ZnCl}_{2} / 0.7 \mathrm{M} \mathrm{MnCl} \cdot \mathrm{H}_{2} \mathrm{O}$ in $2: 1$ urea/ChCl at a potential of $-1.8 \mathrm{~V}$ and temperatures of $20^{\circ} \mathrm{C}, 40^{\circ} \mathrm{C}$ and $60^{\circ} \mathrm{C}$. 


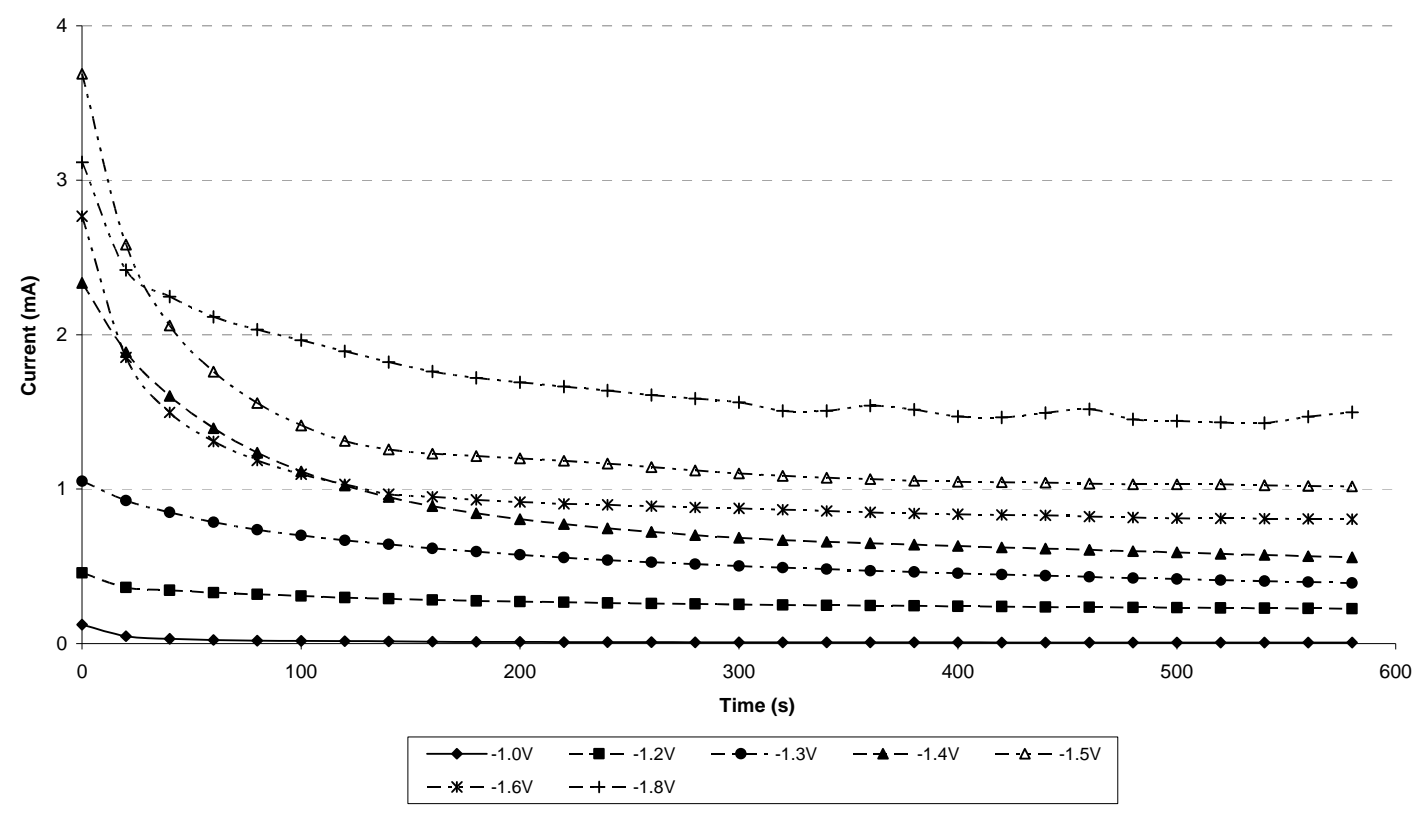

Figure 10 Current-time curves for the deposition of $\mathrm{Zn}$-Mn alloys from $0.4 \mathrm{M}$ $\mathrm{ZnCl}_{2} / 0.7 \mathrm{M} \mathrm{MnCl} 2 . \mathrm{H}_{2} \mathrm{O}$ in $2: 1 \mathrm{urea} / \mathrm{ChCl}$ at $40^{\circ} \mathrm{C}$ and different potentials. 


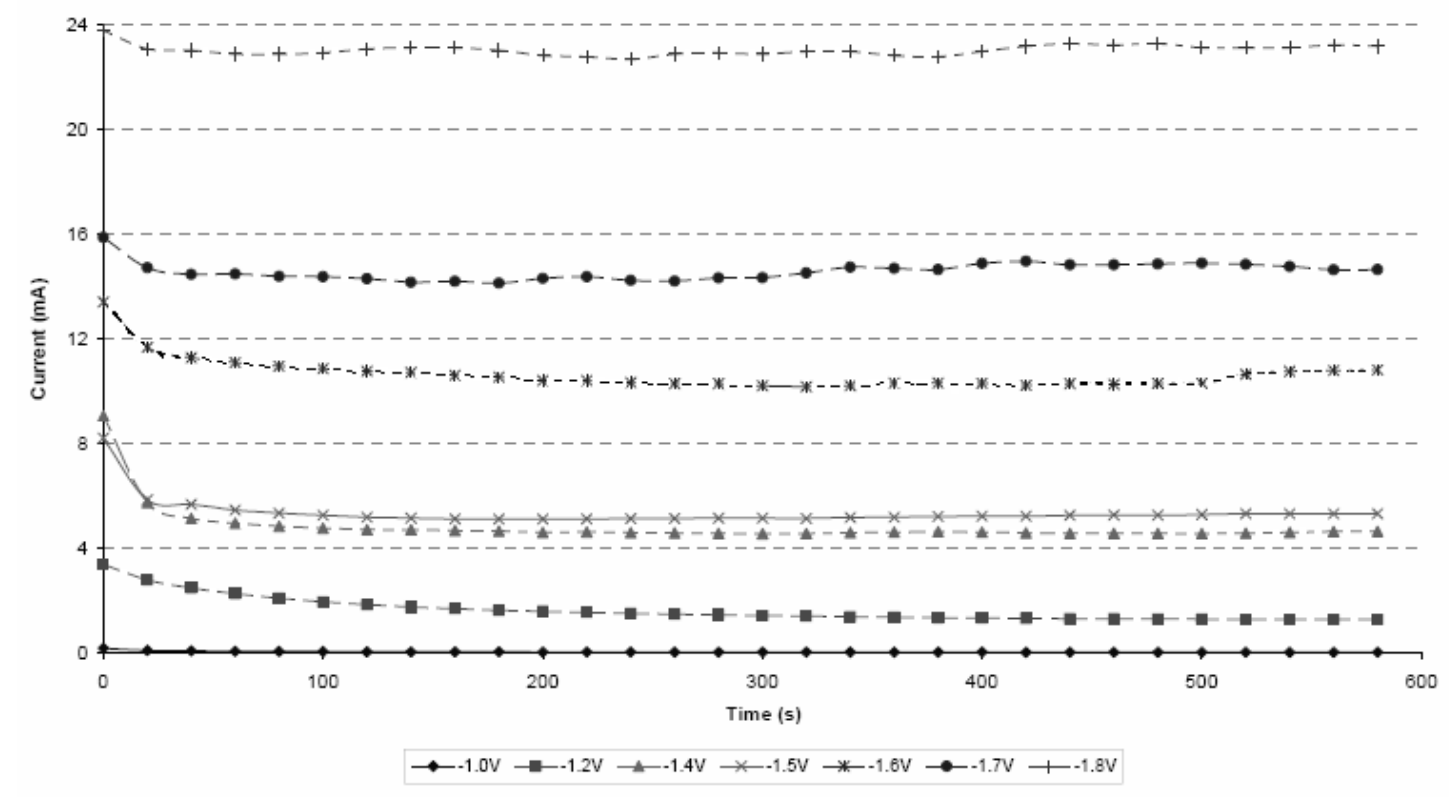

Figure 10 Current-time curves for the deposition of $\mathrm{Zn}-\mathrm{Mn}$ alloys from $0.4 \mathrm{M}$ $\mathrm{ZnCl}_{2} / 0.7 \mathrm{M} \mathrm{MnCl}_{2} \cdot \mathrm{H}_{2} \mathrm{O} / 0.4 \mathrm{M} \mathrm{H}_{3} \mathrm{BO}_{3}$ in $2: 1 \mathrm{urea} / \mathrm{ChCl}$ at $40^{\circ} \mathrm{C}$ and different potentials 


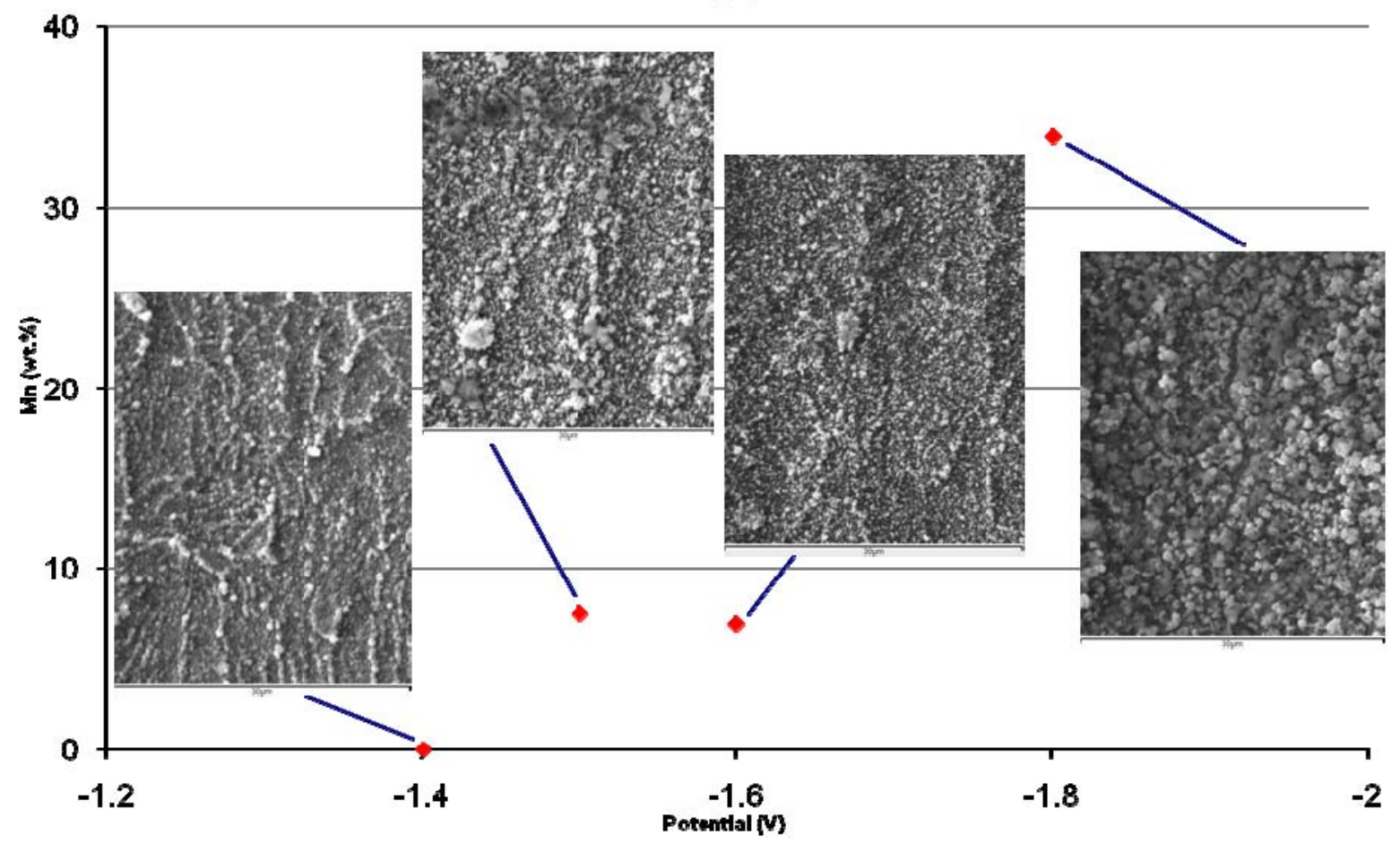

Figure 12 Manganese content and morphology of the electrodeposits from $0.4 \mathrm{M} \mathrm{ZnCl} / 0.7 \mathrm{M} \mathrm{MnCl} 2 . \mathrm{H}_{2} \mathrm{O}$ in $2: 1 \mathrm{urea} / \mathrm{ChCl}$ at $40^{\circ} \mathrm{C}$ as a function of potential. 


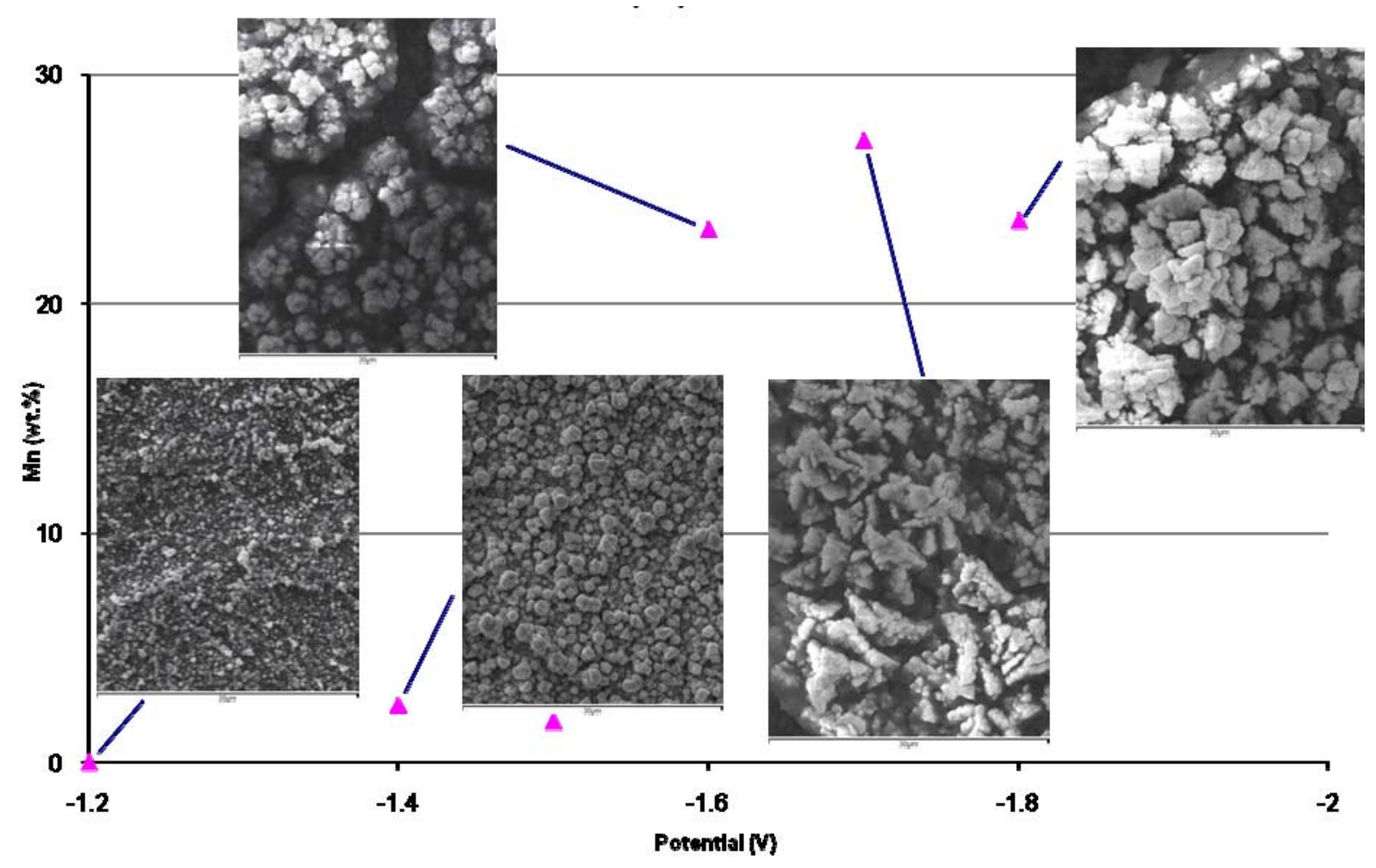

Figure 13 Manganese content and morphology of electrodeposits from $0.4 \mathrm{M}$ $\mathrm{ZnCl}_{2} / 0.7 \mathrm{M} \mathrm{MnCl}_{2} \cdot \mathrm{H}_{2} \mathrm{O} / 0.4 \mathrm{M} \mathrm{H}_{3} \mathrm{BO}_{3}$ in $2: 1$ urea/ $\mathrm{ChCl}$ at $40^{\circ} \mathrm{C}$ as a function of potential. 


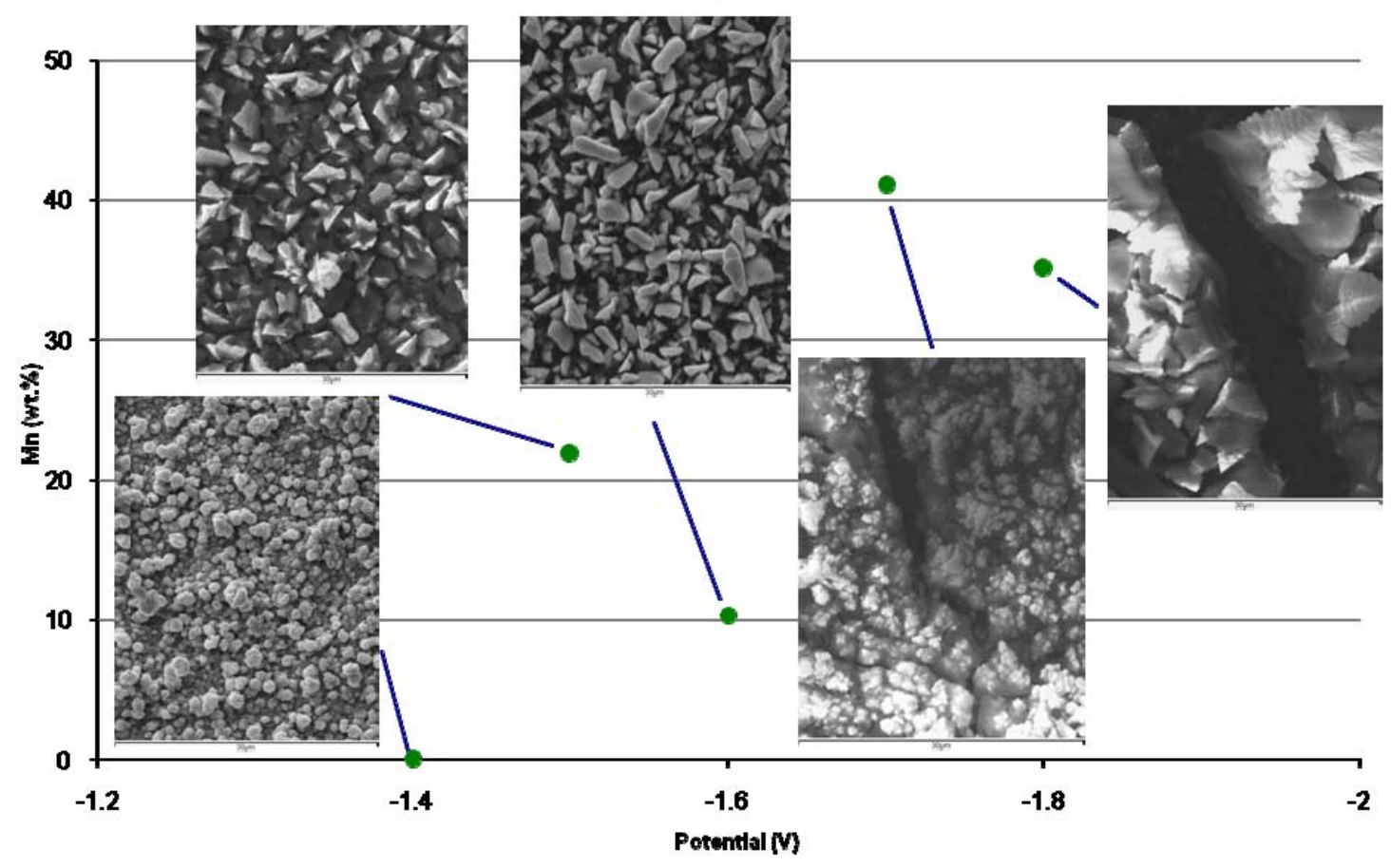

Figure 14 Manganese content and morphology of electrodeposits from $0.4 \mathrm{M}$ $\mathrm{ZnCl}_{2} / 0.7 \mathrm{M} \mathrm{MnCl}_{2} \cdot \mathrm{H}_{2} \mathrm{O} / 0.8 \mathrm{M} \mathrm{H}_{3} \mathrm{BO}_{3}$ in $2: 1$ urea/ $\mathrm{ChCl}$ at $40^{\circ} \mathrm{C}$ as a function of potential. 